\begin{tabular}{ccl}
\hline Jurnal Teknologi Kimia Unimal & $\begin{array}{l}\text { Jurnal } \\
\text { Teknologi } \\
\text { Kimia } \\
\text { Unimal }\end{array}$ \\
\hline
\end{tabular}

\title{
PEMANFAATAN LIMBAH KULIT JENGKOL (Pithecellobium jiringa) MENJADI BIOARANG DENGAN MENGGUNAKAN PEREKAT CAMPURAN GETAH SUKUN DAN TEPUNG TAPIOKA
}

\author{
Rozanna Dewi, Fikri Hasfita \\ Jurusan Teknik Kimia, Fakultas Teknik, Universitas Malikussaleh \\ Jl. Batam No. 1 Bukit Indah, Lhokseumawe 24353 \\ Korespondensi: HP: 081262315868, e-mail: rozanna.dewi@gmail.com
}

\begin{abstract}
Abstrak
Kebutuhan energi yang terus meningkat dan ketersediaaan bahan bakar yang menipis memaksa manusia untuk mencari sumber bahan bakar alternatif. Oleh karena itu, perlu dilakukan penelitian untuk memperoleh bahan bakar alternatif yang dapat diperbarui seperti limbah kulit jengkol. Limbah kulit jengkol merupakan biomassa yang keberadaanya belum termanfaatkan secara optimal. Biomassa limbah kulit jengkol dapat diolah menjadi suatu bentuk bahan bakar padat dengan dimensi tertentu yang seragam, yang diperoleh dari hasil pengempaan bahan berbentuk serbuk dan berukuran relatif kecil yang biasa disebut sebagai bioarang. Perekat yang digunakan dalam penelitian ini adalah campuran getah dengan perekat tepung tapioka. Penelitian ini bertujuan untuk mengkaji mutu bioarang limbah kulit jengkol sebagai energi alternatif. Penelitian dilakukan dengan memvariasikan ukuran partikel limbah kulit jengkol (20, 5080 mesh) dan berat bahan baku (25, 50, 75 gr). Analisa yang dilakukan adalah analisa kadar air, nilai kalor, laju pembakaran, kadar abu dan kadar karbon. Hasil penelitian menunjukkan bahwa nilai kalor terbaik yaitu 5392,079 kal/gr, kadar air 3,908 \%, laju pembakaran 0,190 gr/menit, kadar abu 6\% dan kadar karbon 63,094\% yang didapatkan dari ukuran partikel 80 mesh dan berat bahan baku 50 gr.
\end{abstract}

Kata kunci : Bioarang, Getah Sukun, Kulit Jengkol, Tepung Tapioka

\section{Pendahuluan}

Energi merupakan komponen utama dalam seluruh kegiatan makhluk hidup. Sumber energi yang utama bagi manusia adalah sumber daya alam yang berasal dari fosil karbon. British Petrolium (2005) menyatakan bahwa 45,7\% 
kebutuhan enegri di Indonesia dipenuhi oleh bahan bakar minyak. Jumlah ini setara dengan 55,3 juta ton minyak dan gas elpiji. Cadangan minyak bumi Indonesia hanya tersisa $1 \%$ dan gas bumi hanya $1,4 \%$ dari total cadangan minyak dan gas bumi dunia, sedangkan cadangan batubara hanya $3 \%$ dari cadangan batu-bara dunia. Indonesia diperkirakan akan menjadi pengimpor penuh minyak bumi dan perlu adanya upaya mencari bahan bakar alternatif yang dapat diperbaharui, ramah lingkungan, dan bernilai ekonomis (Anung dan Roy, 2010).

Beberapa energi alternatif yang dapat dikembangkan sebagai pengganti dari minyak bumi adalah gas bumi, batu bara dan biomassa. Gas bumi dan batubara merupakan energi dari fosil sedangkan sedangkan briket itu sendiri merupakan biomassa dan sering dimusnahkan dengan cara dibakar (Ndraha, 2010). Biomassa yang berasal dari limbah hasil pertanian dan kehutanan merupakan bahan yang tidak bernilai guna, tetapi dapat dimanfaatkan menjadi sumber energi bahan bakar alternatif, yaitu dengan mengubahnya menjadi suatu bahan bakar padat yang disebut biobriket atau briket bioarang (Silalahi dalam Erfanti, 2013).

Banyak penelitian terdahulu yang mengkaji tentang bioarang dari berbagai bahan baku, salah satunya Erfanti (2013) dengan judul karakteristik briket bioarang limbah pisang uli dengan perekat tepung tapioka. Ndraha (2010) melakukan penelitian dengan judul uji komposisi bahan pembuat briket bioarang tempurung kelapa dan serbuk kayu terhadap mutu yang dihasilkan. Penelitian lain juga pernah dilakukan oleh Mulyadi, dkk (2013) dengan judul Pemanfaatan Kulit Buah Nipah untuk pembuatan briket bioarang sebagai sumber energi alternatif.

Bhaki, dkk (2013) melakukan penelitian dengan judul pembuatan briket kulit durian dengan variasi campuran biomassa (arang cangkang sawit) dan variasi perekat. Usman (2011) melakukan penelitian dengan judul mutu briket arang kulit buah kakao dengan menggunakan kanji sebagai perekat. Aristiyanto (2014) melakukan penelitian dengan judul pembuatan biobriket dari campuran limbah kulit pisang dan serbuk gergaji menggunakan perekat tetes tebu. 
Penelitian untuk mencari sumber energi alternatif terus dikembangkan terutama yang bersumber dari biomassa, salah satu yang akan diteliti adalah kulit jengkol dengan menggunakan perekat getah sukun yang dicampur dengan tepung tapioka. Hasil penelitian diharapkan dapat diperoleh informasi tentang pengembangan kulit jengkol dan getah sukun sebagai bahan bakar alternatif. Kulit Jengkol (Pithecellobium jiringa) selama ini tergolong limbah organik yang berserakan di pasar tradisional dan tidak memberikan nilai ekonomis. Hal tersebut menunjukkan bahwa perhatian akan kulit jengkol masih sangat kurang.

Tanaman sukun (Artocarpus altilis) merupakan tanaman tropik, tumbuh yang paling baik di dataran rendah yang panas. Tanaman ini dapat digolongkan menjadi sukun yang berbiji (breadnut) dan yang tanpa biji (breadfruit). Sukun (Artocarpus altilis) tergolong. Buah sukun (Artocarpus altilis) merupakan sumber karbohidrat. Apabila batang dan buah tanaman ini dilukai maka akan mengeluarkan cairan putih kental yang disebut getah. Getah ini biasanya tidak dimanfaatkan dan dibuang begitu saja sebagai limbah.

Dalam makalah ini dibahas tentang pemanfaatkan limbah kulit jengkol dan getah sukun menjadi bioarang sebagai bahan bakar alternatif sehingga dapat meningkatkan nilai ekonomis dari tanaman jengkol dan buah sukun serta mengurangi dampak limbah di lingkungan.

\section{Bahan dan Metode}

\subsection{Alat dan bahan yang digunakan}

Adapun alat-alat dan bahan yang digunakan dalam penelitian ini adalah Kulit jengkol, Getah sukun,Tepung Tapioka, Air sebagai campuran bahan perekat, Drum, Neraca digital, Batang Pengaduk, Cetakan bioarang, Oven, Desikator, Calorimeter dan Cawan Porselin.

\subsection{Prosedur Kerja}

Proses Persiapan Bahan Baku 
1. Kulit jengkol dibersihkan kemudian dijemur dibawah sinar matahari selama 3 hari.

2. Kulit jengkol dimasukkan ke dalam tungku pengarangan secara bertahap.

3. Kemudian bahan disulut dengan api dan dikeluarkan dari tungku pengarangan setelah bahan menjadi arang dan didinginkan selama 30 menit.

4. Kemudian ditumbuk hingga halus.

5. Diayak dengan variasi ukuran mesh (20, 50, 80 mesh) sehingga menjadi serbuk.

6. Serbuk arang kulit jengkol siap dicampur dengan perekat.

Proses Pencampuran Bahan Baku Dengan Perekat

1. Pembuatan perekat tepung tapioka dilakukan dengan cara mengencerkan tepung tapioka dengan air dengan perbandingan 1:16 (b/v).

2. Campuran kemudian dipanaskan sampai matang.

3. Perekat yang sudah matang ditandai dengan perubahan warna campuran dari putih keruh menjadi bening.

4. Ditimbang 20 gr perekat tepung tapioka dan 10 gr getah sukun, dicampur jadi satu dan diaduk sampai homogen.

5. Ditimbang serbuk arang kulit jengkol sesuai variasi 25, 50 dan 75 (gr).

6. Setelah ditimbang dicampur serbuk arang dan perekat, serta dilakukan pengadukan.

Proses pencetakan briket bioarang

1. Campuran yang telah dibuat kemudian dicetak menggunakan cetakan pipa besi berbentuk silinder.

2. Dimasukkan adonan ke dalam cetakan. 
3. Dilakukan pengepresan dan didiamkan beberapa menit.

4. Briket dikeluarkan dari cetakan dan diletakkan secara teratur di dalam oven.

5. Dipanaskan dengan suhu $105^{\circ} \mathrm{C}$ selama 3 jam.

6. Briket yang dihasilkan kemudian diuji parameternya yaitu kadar air, nilai kalor, laju pembakaran, kadar abu dan kadar karbon terikat.

\subsection{Analisa}

Kadar air

Analisa kadar air bahan dilakukan dengan cara menghitung berat kering oven. Sebelum bahan kering diovenkan, diambil sampel dari setiap perlakuan. Kemudian ditimbang setiap 5 gram di cawan porselin yang telah diketahui berat kosongnya. Dikeringkan di dalam oven selama 3 jam dengan suhu $105^{\circ} \mathrm{C}$.

Didinginkan di dalam desikator selama 15 menit lalu ditimbang.

Kadar air dihitung dengan rumus:

Kadar Air $(\%)=($ Berat awal-Berat akhir $)$ Berat awal $\times 100 \%$

Analisa Nilai Kalor

Prosedur analisa nilai kalor adalah sebagai berikut:

1. Ditimbang 1 gr sampel ke dalam cawan besi.

2. Disiapkan rangkaian bom kalorimeter dan dipasang cawan ke rangkaian bom kalorimeter.

3. Dihubungkan dengan kawat platina dan disentuhkan dengan sampel.

4. Dimasukkan air sebanyak $1 \mathrm{ml}$ ke dalam bejana bom kalorimeter, lalu dimasukkan rangkaian bom kalorimeter ke dalam bejana.

5. Ditutup rapat dan diisi dengan gas dengan tekanan $130 \mathrm{~atm}$. 
6. Diisi ember bom kalorimeter dengan 2 liter air dan dimasukkan ke dalam jaket bom kalorimeter.

7. Dimasukkan bejana bom ke dalam ember kemudian ditutup.

8. Dijalankan mesin dan dilihat suhu awal.

9. Setelah 5 menit ditekan tombol pembakaran dan dibiarkan selama 7 menit.

10. Dilihat suhu akhir dan dimatikan mesin.

11. Dihitung nilai kalor dengan persamaan :

$\mathrm{HHV}=T 1-T 2 \times 2458 m$

Dimana: $\mathrm{HHV}=$ kualitas nilai $\mathrm{kalor}(\mathrm{kal} / \mathrm{g})$

$\mathrm{T} 1=$ Temperatur awal $(\mathrm{C})$

$\mathrm{T} 2=$ Temperatur akhir $(\propto \mathrm{C})$

$\mathrm{m}=$ massa sampel (gr) (Ndraha, 2009)

Analisa Laju Pembakaran

Prosedur analisa laju pembakaran adalah sebagai berikut:

1. Sampel ditimbang sebanyak 5 gr.

2. Kemudian sampel disulutkan dengan api dan dihidupkan stopwatch sampai sampel habis terbakar.

3. Dicatat waktu dimana api mulai menyambar sampai sampel habis terbakar.

4. Diulangi analisa tiga kali.

5. Dilakukan perhitungan dengan rumus:

Laju Pembakaran $(\mathrm{gr} / \mathrm{menit})=$ gr sampel $(\mathrm{gr})$ waktu pembakaran $(\mathrm{mnt})$

Analisa Kadar Abu 
Prosedur analisa kadar abu adalah sebagai berikut:

1. Cawan porselin yang telah bersih diovenkan pada suhu $105^{\circ} \mathrm{C}$ selama 2 jam.

2. Didinginkan dalam desikator selama $1 \frac{1}{2}$ jam kemudian ditimbang (A gram).

3. Ke dalam cawan porselin ditimbang lebih kurang 3 gram contoh (B gram).

4. Ditanurkan pada suhu $650^{\circ} \mathrm{C}$ selama 3 jam dan didinginkan dalam desikator selama $1 / 2$ jam kemudian ditimbang ( $\mathrm{C}$ gram).

5. Dilakukan perhitungan dengan rumus:

Kadar Abu $(\%)=B-C B x 100 \% \quad($ Sinurat, 2011)

Analisa Kadar Zat Terbang

Prosedur analisa kadar zat terbang adalah sebagai berikut:

1. Cawan porselin yang telah bersih diovenkan pada suhu $105 \square \mathrm{C}$ selama 2 jam.

2. Didinginkan dalam desikator selama $1 / 2$ jam kemudian ditimbang (A gram).

3. Ke dalam cawan porselin ditimbang lebih kurang 3 gram contoh (B gram).

4. Ditanurkan pada suhu $900^{\circ} \mathrm{C}$ selama 7 menit dan didinginkan dalam desikator selama $1 / 2$ jam kemudian ditimbang (C gram).

5. Dilakukan perhitungan dengan rumus:

Kadar zat terbang $(\%)=B-C B x 100 \% \quad($ Sinurat, 2011)

Analisa Kadar Karbon

Kadar karbon terikat dihitung dari 100\% dikurangi dengan kadar air dikurangi kadar abu, dikurangi kadar zat terbang.

Kadar Karbon $(\%)=100 \%$ - kadar air - kadar abu - kadar zat terbang (Sinurat, 2011) 


\section{Hasil dan Diskusi}

Tabel 1. Data hasil penelitian

\begin{tabular}{|c|c|c|c|c|c|c|c|}
\hline No & $\begin{array}{l}\text { Berat } \\
\text { Serbuk } \\
\text { Kulit } \\
\text { Jengko } \\
1 \text { (gr) }\end{array}$ & $\begin{array}{l}\text { Ukuran } \\
\text { Partikel } \\
\text { (Mesh) }\end{array}$ & $\begin{array}{l}\text { Kadar } \\
\text { Air } \\
(\%)\end{array}$ & $\begin{array}{l}\text { Nilai } \\
\text { Kalor } \\
\text { (kal/gr) }\end{array}$ & $\begin{array}{c}\text { Laju } \\
\text { Pembakaran } \\
\text { (gr/menit) }\end{array}$ & $\begin{array}{c}\text { Kadar } \\
\text { Abu } \\
(\%)\end{array}$ & $\begin{array}{l}\text { Kadar } \\
\text { Karbon } \\
(\%)\end{array}$ \\
\hline 1 & \multirow{3}{*}{25} & 20 & 4,252 & 4523,124 & 0.215 & 7,085 & 61,243 \\
\hline 2 & & 50 & 4,469 & 4835,028 & 0.198 & 6,892 & 61,349 \\
\hline 3 & & 80 & 4,774 & 4923,221 & 0.176 & 6,494 & 61,622 \\
\hline 4 & \multirow{3}{*}{50} & 20 & 3,606 & 4983,389 & 0.231 & 6,827 & 62,557 \\
\hline 5 & & 50 & 3,773 & 5187,017 & 0.215 & 6,133 & 63,094 \\
\hline 6 & & 80 & 3,908 & 5392.079 & 0.190 & 5,998 & 63,235 \\
\hline 7 & \multirow{3}{*}{75} & 20 & 3,263 & 4752,336 & 0.330 & 6,766 & 62,782 \\
\hline 8 & & 50 & 3,152 & 4889,252 & 0.281 & 6,338 & 63,080 \\
\hline 9 & & 80 & 3,738 & 5123,115 & 0.267 & 6,147 & 63,095 \\
\hline
\end{tabular}

\section{Pengaruh Ukuran Partikel dan Berat Bahan Baku Terhadap Kadar Air}

Kadar air mempengaruhi kualitas briket yang dihasilkan. Kadar air pada briket diharapkan serendah mungkin agar dapat menghasilkan nilai kalor yang tinggi dan akan menghasilkan briket yang mudah dalam penyalaan atau pembakaran awalnya. Semakin rendah kadar air semakin tinggi nilai kalor dan daya pembakarannya. Sebaliknya, briket dengan kadar air yang tinggi akan menyebabkan nilai kalor yang dihasilkan briket tersebut menurun. Hal ini disebabkan energi yang dihasilkan akan banyak terserap untuk menguapkan air. Briket dengan kadar air yang tinggi, menyebabkan kualitas briket menurun ketika penyimpanan karena mikroba dapat berkembang biak. Kadar air yang tinggi juga dapat menimbulkan asap yang banyak saat pembakaran (Riseanggara, 2008). Hasil penelitian untuk parameter kadar air disajikan pada Gambar 1. 


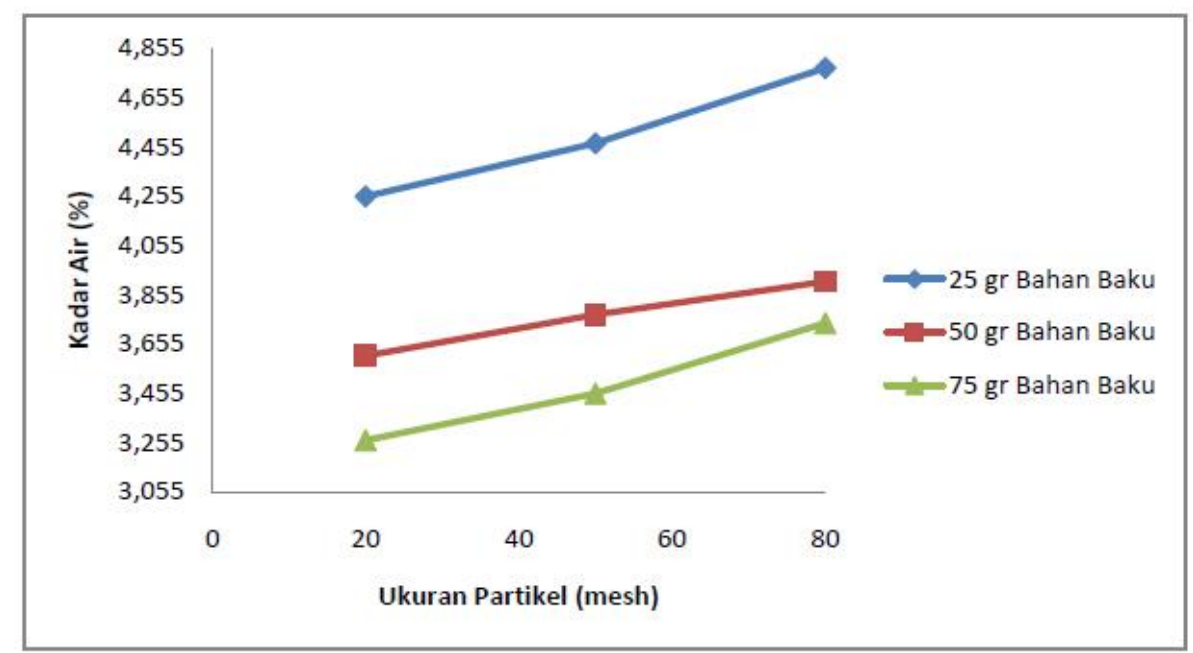

Gambar 1. Grafik Hubungan Antara Ukuran Partikel dan Bahan Baku Terhadap kadar air

Gambar 1 menunjukkan bahwa kadar air tertinggi adalah 4,774\% yang berada pada 25 gr bahan baku dengan ukuran partikel 80 mesh. Sedangkan kadar air terendah adalah 3,263\% yang berada pada 75 gr bahan baku dengan ukuran partikel 20 mesh. Hasil penelitian berdasarkan tabel 1 range kadar air yang dihasilkan adalah 3,263\% - 4,774\%. Dapat kita lihat bahwa semakin kecil ukuran partikel maka persentase kadar air juga semakin meningkat. Hal ini terjadi karena semakin kecil ukuran partikel maka akan semakin banyak terserap air sehingga persentase kadar air yang dihasilkan juga semakin rendah dan sebaliknya semakin besar ukuran partikel semakin sedikit menyerap air karena luas permukaan partikel semakin kecil.

Tingginya kadar air bioarang dengan 25 gr bahan baku diakibatkan karena bentuk fisik dari bioarang pada penelitian ini lebih cair jika dibandingkan dengan menggunakan bahan baku 50 gr. Kadar air hasil penelitian ini tidak jauh berbeda dengan kadar air briket arang kayu yang sudah ada di pasar. Secara keseluruhan kadar air untuk briket arang kayu berkisar antara 3,57\% - 4,75\% (Hendra dan Dermawan, 2000). Sehingga dapat disimpulkan bioarang hasil penelitian memiliki nilai kadar air yang sesuai dengan briket standar yaitu 3,263\% - 4,774\%. 
Kadar air yang didapat pada penelitian ini menunjukkan adanya kecenderungan semakin banyak konsentrasi serbuk kulit jengkol yang ditambahkan pada pembuatan bioarang, maka kadar air akan semakin menurun. Faktor lain yang dapat menyebabkan rendahnya kadar air suatu briket adalah pada lamanya waktu pengeringan briket itu sendiri. Semakin lama pengeringan yang dilakukan maka semakin banyak air yang terbuang, sehingga kadar air briket arang yang dihasilkan semakin rendah (Sunyata, 2004). Selain pengeringan konvensional atau dengan memanfaatkan sinar matahari, pengeringan bioarang juga dapat dilakukan dengan menggunakan pengeringan dalam oven.

\section{Pengaruh Ukuran Partikel dan Berat Bahan Baku Terhadap Nilai Kalor}

Nilai kalor perlu diketahui dalam pembuatan bioarang agar diketahui nilai panas pembakaran yang dapat dihasilkan oleh bioarang sebagai bahan bakar. Semakin tinggi nilai kalor yang dihasilkan oleh bahan bakar bioarang maka akan semakin baik pula kualitasnya. Semakin tinggi berat jenis bahan bakar, maka semakin tinggi nilai kalor yang diperolehnya. Hasil penelitian untuk parameter nilai kalor disajikan pada Gambar 2.

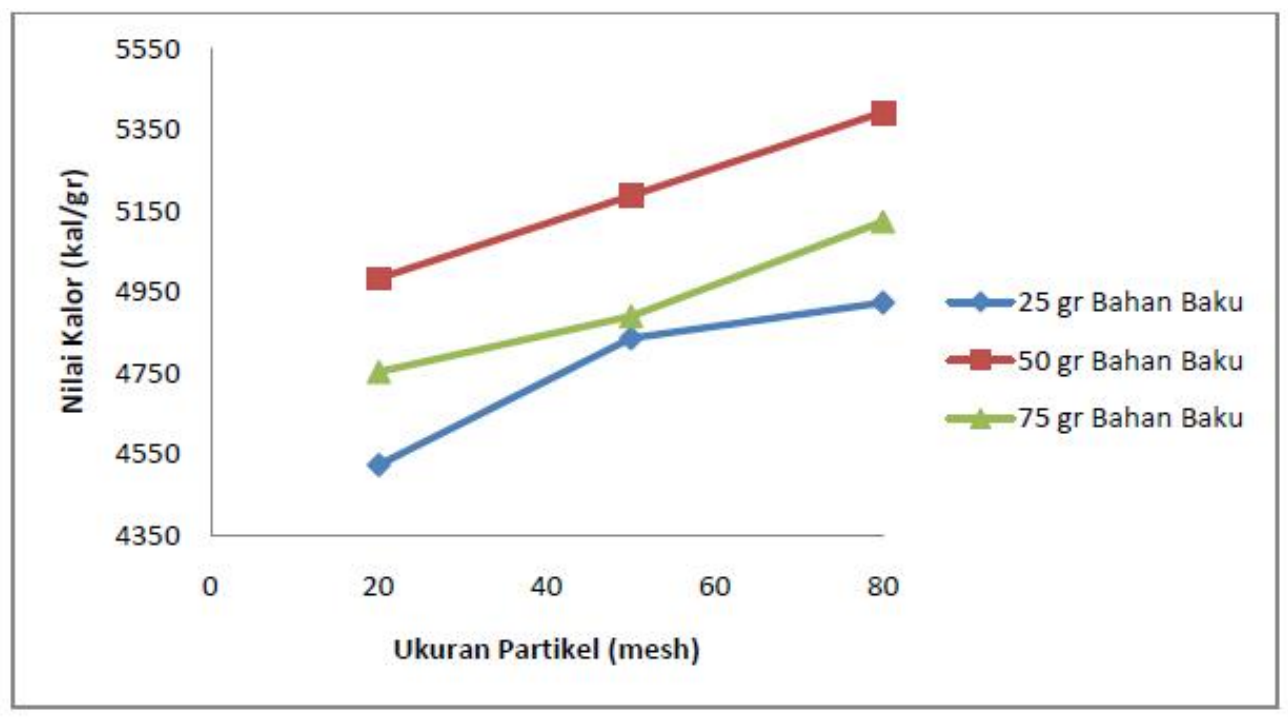

Gambar 2. Grafik Hubungan Antara Ukuran Partikel dan Berat Bahan Baku Terhadap Nilai Kalor 
Gambar 2 menunjukkan bahwa nilai kalor tertinggi adalah 5392,079 kal/gr yang berada pada 50 gr bahan baku dengan ukuran partikel 80 mesh. Sedangkan nilai kalor terendah adalah $4523,124 \mathrm{kal} / \mathrm{gr}$ yang berada pada 50 gr bahan baku dengan ukuran partikel 80 mesh. Hasil penelitian berdasarkan tabel 1 range nilai kalor yang dihasilkan adalah 4523,124 kal/gr - 5392,079 kal/gr.

Berdasarkan gambar 2 dapat kita lihat bahwa semakin kecil ukuran partikel maka nilai kalorinya makin tinggi, demikian juga semakin kecil ukuran partikel semakin tinggi pula kerapatannya, hal ini sejalan dengan Sudrajat (1983), mengatakan bahwa kayu dengan berat jenis tinggi, cenderung menghasilkan briket dengan nilai kalori tinggi. Nilai kalori bioarang sangat penting karena ada kaitannya dengan efisiensi atau penghematan suatu bahan bakar. Apabila nilai kalor rendah berarti jumlah bahan bakar yang digunakan dan dibutuhkan untuk pembakaran akan lebih banyak, tetapi bila nilai kalornya tinggi berarti jumlah bahan bakar yang digunakan untuk pembakaran akan lebih sedikit, nilai kalor bioarang merupakan parameter penting dalam menentukan kualitas bioarang, layak atau tidak digunakan sebagai bahan bakar.

Semakin tinggi nilai kalor suatu briket arang makin tinggi pula kualitasnya dan harga jualnya pun akan tinggi. Bila dibanding dengan standar briket arang buatan Indonesia (6814 kal/gr) dan briket arang buatan impor (6000-7000 kal/gr), maka briket arang kulit jengkol dari semua perlakuan partikel 20 mesh, 50 mesh dan 80 mesh semuanya tidak memenuhi standar mutu, yang berarti briket kulit jengkol mempunyai nilai kalor yang lebih rendah dari nilai kalor standar briket arang buatan Indonesia dan hanya sebanding dengan nilai kalor kayu bakar (4500$5000 \mathrm{kal} / \mathrm{gr})$.

Berdasarkan penelitian yang telah dilakukan sebelumnya oleh Manik (2010). Kualitas nilai kalor suatu briket akan meningkat seiring dengan bertambahnya bahan perekat dalam briket tersebut. Bahan perekat memiliki sifat dapat meningkatkan nilai kalor karena mengandung unsur C (Manik, 2010). Tetapi bila bahan baku yang digunakan tidak sesuai dengan banyaknya jumlah 
perekat maka nilai kalor yang dihasilkan juga akan semakin berkurang. Apabila jumlah bahan baku lebih kecil dari jumlah perekat maka akan meningkatkan kadar air. Tingginya kadar air akan menyebabkan penurunan nilai kalor. Hal ini disebabkan karena panas yang tersimpan dalam briket terlebih dahulu digunakan untuk mengeluarkan air yang ada sebelum kemudian menghasilkan panas yang dapat dipergunakan sebagai panas pembakaran (Hendra, 2000).

Apabila jumlah bahan baku lebih besar dari jumlah perekat maka akan mempengaruhi kerapatan bioarang yang dihasilkan. Semakin kecil kerapatan bioarang maka nilai kalor juga akan semakin kecil. Kerapatan bioarang juga sangat berguna dalam transportasi dan pengepakan agar bioarang tidak mudah hancur (Usman, 2007).

\section{Pengaruh Ukuran Partikel dan Berat Bahan Baku Terhadap Laju Pembakaran}

Laju pembakaran adalah penggambaran berkurangnya bobot per satuan menit selama pembakaran. Pengurangan bobot semakin cepat memberikan laju pembakaran yang besar. Semakin besar laju pembakaran, maka menyala briket akan semakin singkat.

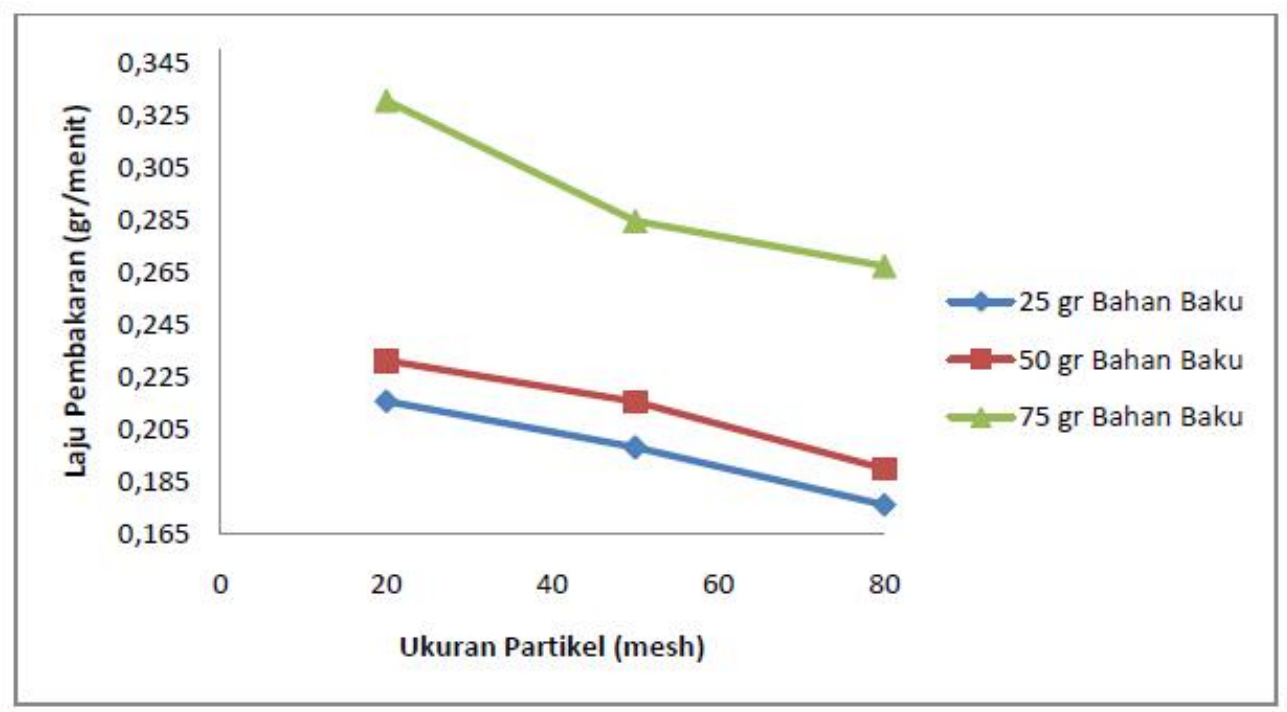

Gambar 3. Grafik Hubungan Antara Ukuran Partikel dan Berat Bahan Baku Terhadap Laju Pembakaran 
Gambar 3 menunjukkan bahwa laju pembakaran tertinggi adalah 0,330 gr/menit yang berada pada 75 gr bahan baku dengan ukuran partikel 20 mesh. Sedangkan laju pembakaran terendah adalah $0,176 \mathrm{gr} /$ menit yang berada pada 25 gr bahan baku dengan ukuran partikel 80 mesh. Hasil penelitian berdasarkan tabel 4.1 range laju pembakaran yang dihasilkan adalah 0,176 gr/menit - 0,330 gr/menit. Laju pembakaran yang dihasilkan lebih rendah dari laju pembakaran briket arang kayu 1,153 g/menit dan juga paraffin 3,333 g/menit.

Berdasarkan grafik diatas dapat kita lihat bahwa semakin kecil ukuran partikel maka laju pembakaran semakin berkurang. Hal ini dipengaruhi oleh kerapatan bioarang, semakin kecil ukuran partikel maka kerapatan bioarang yang dihasilkan semakin besar. Semakin rendah kerapatan bioarang maka akan memiliki rongga udara yang lebih besar sehingga jumlah bahan yang terbakar lebih banyak dibanding dengan bioarang yang memiliki kerapatan yang besar. Sehingga ketika jumlah bahan yang terbakar semakin besar per menitnya maka akan memiliki laju pembakaran yang semakin kecil (Pabisa, 2013). Menurut Riseanggara (2008), berkurangnya rongga udara pada briket dengan kerapatan yang lebih tinggi akan memperlambat laju pembakaran.

Jumlah bahan baku yang digunakan juga mempengaruhi laju pembakaran semakin kecil jumlah bahan baku dari jumlah perekat maka semakin rendah laju pembakaran. Rendahnya laju pembakaran akibat tingginya perekat disebabkan oleh kandungan bahan organik yang ada pada perekat itu sendiri yang menyebabkan briket menjadi padat sehingga menyulitkan proses pembakarannya (Riseanggara, 2008).

Pada saat pembakaran briket bioarang kulit jengkol bau asap yang dihasilkan tidak begitu menyengat dibandingkan dengan bau kulit jengkol yang sebelum dijadikan briket. Hal ini mungkin karena kulit jengkol telah dikarbonasi/pengarangan terlebih dahulu. Kemudian pada saat dilakukan pengujian dibakar jagung dengan menggunakan briket bioarang kulit jengkol, 
aroma jagung bakar agak sedikit berbau jengkol tetapi rasanya tetap sama dengan jagung yang dibakar dengan arang kayu.

\section{Pengaruh Ukuran Partikel dan Berat Bahan Baku Terhadap Kadar Abu}

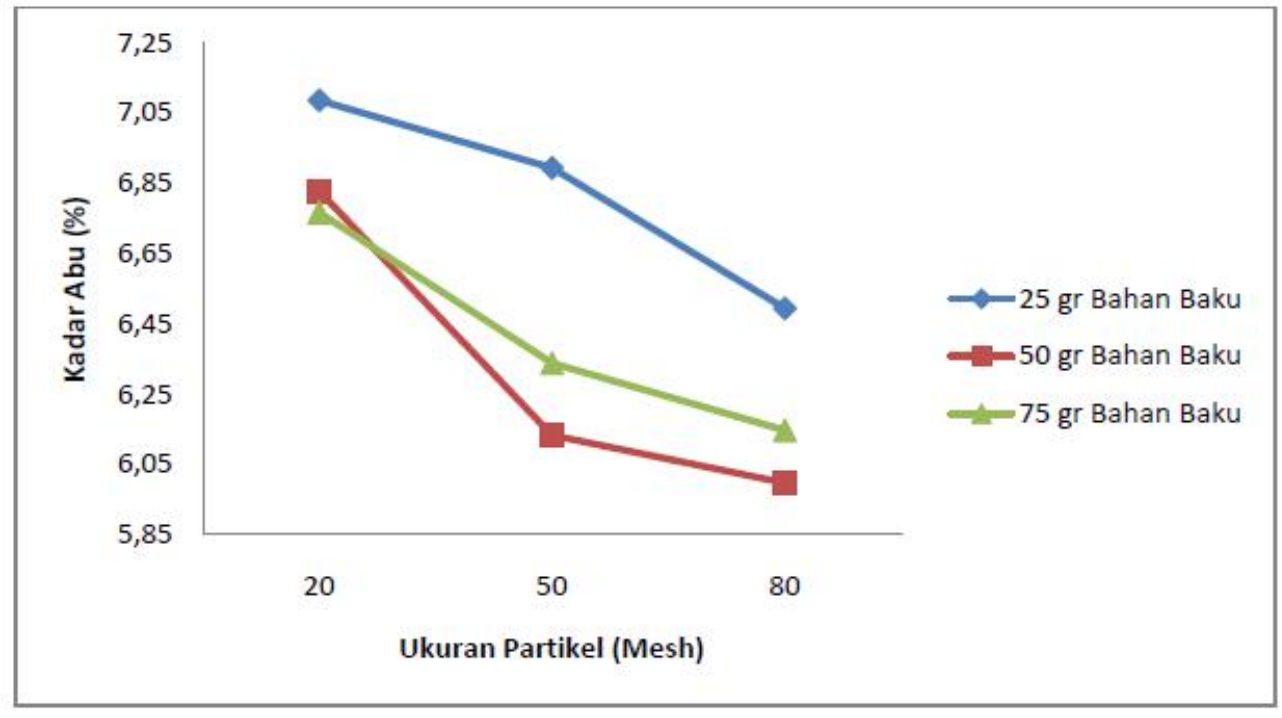

Gambar 4. Grafik Hubungan Antara Ukuran Partikel dan Berat Bahan Baku Terhadap Kadar Abu

Gambar 4 menunjukkan bahwa kadar abu tertinggi adalah 7,08 \% yang berada pada 25 gr bahan baku dengan ukuran partikel 20 mesh. Sedangkan kadar abu terendah adalah $6 \%$ yang berada pada 50 gr bahan baku dengan ukuran partikel 80 mesh. Hasil penelitian berdasarkan tabel 1 range laju pembakaran yang dihasilkan adalah $6 \%-7,08 \%$.

Berdasarkan grafik diatas dapat kita lihat bahwa semakin kecil ukuran partikel maka kadar abu semakin rendah dan sebaliknya semakin besar ukuran partikel maka kadar abu semakin tinggi. Hal ini diduga karena jumlah silika yang terkandung didalam partikel, semakin besar ukuran partikel maka jumlah silikanya semakin banyak sehingga kadar abunya juga semakin tinggi. Menurut Hendra dan Darmawan (2000), salah satu unsur kadar abu adalah silika dan pengaruhnya kurang baik terhadap nilai kalor yang dihasilkan. Semakin rendah 
kadar abu maka semakin baik kualitas briket yang dihasilkan. Kadar abu yang dihasilkan juga sangat erat hubungannya dengan bahan penyusun briket tersebut dan mineral yang terkandung didalamnya. Hal ini sesuai dengan literatur Sudarmadji, dkk (1989), bahwa kandungan abu tergantung dari bahan baku dan komposisinya (Ndraha, 2009).

Menurut Ringkuangan, dkk (1993) briket buatan Inggris menghasilkan kadar abu 8,26\% dan briket buatan Jepang menghasilkan kadar abu 5-7\%. Sedangkan menurut Sinurat (2011) briket buatan Indonesia menghasilkan kadar abu 5,26\% dan briket buatan impor 5-6\%. Kadar abu yang dihasilkan dalam penelitian ini belum memenuhi standar mutu briket buatan Indonesia dan impor tetapi memenuhi standar mutu briket buatan Inggris dan Jepang.

\section{Pengaruh Ukuran Partikel dan Berat Bahan Baku Terhadap Kadar Karbon Terikat}

Kandungan karbon terikat pada briket arang dipengaruhi oleh nilai kadar air, kadar abu dan kadar zat terbang. Kadar karbon terikat akan bernilai tinggi apabila nilai kadar air, kadar abu dan kadar zat terbang rendah. Briket yang baik memiliki kadar karbon tinggi.

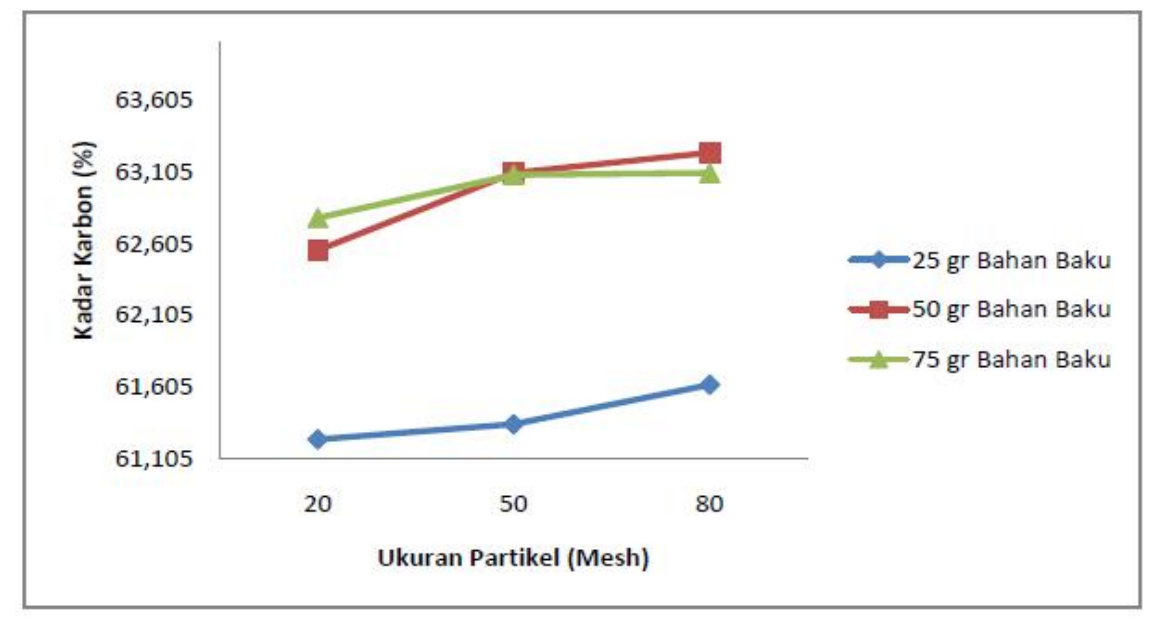

Gambar 5. Grafik Hubungan Antara Ukuran Partikel dan Berat Bahan Baku Terhadap Kadar Karbon 
Gambar 5. menunjukkan bahwa kadar karbon tertinggi adalah 63,235\% yang berada pada $50 \mathrm{gr}$ bahan baku dengan ukuran partikel 80 mesh. Sedangkan kadar karbon terendah adalah $61,243 \%$ yang berada pada 25 gr bahan baku dengan ukuran partikel 20 mesh.

Berdasarkan gambar 4. dapat kita lihat bahwa semakin kecil ukuran partikel maka persentase kadar karbon makin tinggi dan sebaliknya semakin besar ukuran partikel maka persentase kadar karbon semakin rendah. Hal ini dipengaruhi oleh persentase kadar air, kadar abu dan kadar zat terbang dari briket tersebut. Semakin rendah kadar air, kadar abu dan kadar zat terbangnya maka semakin tinggi persentase kadar karbon yang dihasilkan sehingga semakin bagus kualitas briket yang dihasilkan.

Range kadar karbon yang dihasilkan dalam penelitian ini adalah 61,243\% $63,235 \%$. Bila dibandingkan dengan standar mutu briket arang buatan Indonesia (77,36\%), Jepang (60-80\%) dan Amerika (60\%), maka briket arang kulit jengkol dari semua perlakuan tidak memenuhi standar mutu Indonesia tetapi memenuhi standar mutu Jepang dan Amerika.

\section{Simpulan}

Limbah kulit jengkol dapat dimanfaatkan menjadi bahan baku bioarang. Kualitas bioarang yang dihasilkan dari kulit jengkol dipengaruhi oleh ukuran Partikel dan berat bahan baku. Kondisi terbaik bioarang didapatkan pada ukuran partikel 80 mesh dan 50 gr bahan baku dengan nilai kalor yang dihasilkan $5392,079 \mathrm{kal} / \mathrm{gr}$, kadar air 3,908 \%, laju pembakaran 0,190 gr/menit, kadar abu 6\% dan kadar karbon 63,094\%.

\section{Daftar Pustaka}

1. Anung dan Roy, A. 2010. Pemanfaatan arang batok kelapa dan tanah humus baturaden untuk memurnikan kadar logam krom (Cr). Molekul, vol. 5. No. 2, Nov. 2010: 66-74. UNSOED.

2. Adimihardja, Kusnaka. 2005. Makanan dalam Khazanah Budaya. Jawa Barat: UPT Intrik. 
3. Abdullah, Ahmad dan Soedarmanto; 1979. Budidaya Sukun. Jakarta: C.V.Yasaguna. Badan Standarisasi Nasional. 2005. Emisi Gas Buang. SNI 19-7117. 11-2005.

4. Budiman, S., Sukrido, dan Harliana, A. Tanpa tahun. Pembuatan Biobriket dari Campuran Bungkil Biji Jarak Pagar (Jatropha curcas L.) dengan Sekam sebagai Bahan Bakar Alternatif. Semarang: Universitas Diponegoro.

5. $\quad$ Erfanti, Ika. 2013. Karakteristik Briket Bioarang Limbah Kulit Pisang Uli (Musa paradisiaca L.) Dengan Perekat Tepung Tapioka. Skripsi Universitas Sunan Kalijaga.

6. Gandhi, A. 2010. Pengaruh Variasi Jumlah Campuran Perekat Terhadap Karakteristik Briket Arang Tongkol Jagung. Profesional. 8(1): $1-11$.

7. Hendra dan Darmawan, 2000. Pengaruh Bahan Baku, Jenis Perekat dan Tekanan Kempa Terhadap Kualitas Briket Arang. Puslitbang Hasil Hutan. Bogor.

8. Hendra D dan Pari G. 2000. Penyempurnaan Teknologi Pengolahan Arang. Laporan Hasil Penelitian Hasil Hutan. Balai Penelitian dan Pengembangan kehutanan, Bogor.

9. Ikhsan, dkk. 2009. Pelatihan Pemanfaatan Kulit Jengkol (Pithecellobium jiringa) Menjadi Herbisida dan Larvasida Aedesaegepty di Daerah Bandar Setia Kabupaten Deli Serdang Sumatera Utara (PKMM). Medan: Universitas Negeri Medan.

10. Jamilatun, S. 2008. Sifat-Sifat Penyalaan dan Pembakaran Briket Biomassa, Briket Batubara dan Arang Kayu. Jurnal Rekayasa Proses. 2(2): 39-40.

11. Kurniawan dan Marsono. 2008. Superkarbon Bahan bakar Alternatif Pengganti Minyak Tanah Dan Gas. Penebar Swadaya, Depok. 
12. Manik FS. 2010. Pemanfaatan Spent Bleaching Earth dari Proses Pemucatan CPO sebagai Bahan Baku Briket. Bogor: Institut Pertanian Bogor.

13. Mulyadi, dkk. 2013. Pemanfaatan Kulit Buah Nipah. Jurnal Teknologi Pertanian Vol. 14 (1): 65-72.

14. Ndraha, Nodali. 2009. Uji komposisi bahan pembuat briket bioarang tempurung kelapa dan serbuk kayu terhadap mutu yang dihasilkan. Skripsi USU.

15. Nugroha, S. 2008. Pemanfaatan Sekam sebagai Bahan Bakar Murah. Informasi Ringkas Balai Besar Penelitian dan Bank Pengetahuan Padi Indonesia.

16. Pabisa, Junaedy. 2013. Pembuatan briket dari limbah sortiran biji kakao (Theobroma cacao). Skripsi Universitas Hasanuddin.

17. Riseanggara, RR. 2008. Optimasi Kadar Perekat pada Briket Limbah Biomassa. Bogor: Perpustakaan Institut Pertanian Bogor.

18. Santosa, Mislaini dan Anugrah S. P. Tanpa tahun. Studi Variasi Komposisi Bahan Penyusun Briket dari Kotoran Sapi dan Limbah Pertanian. Padang : Universitas Andalas.

19. Sinurat, Erikson. 2011. Studi Pemanfaatan Briket Kulit Jambu Mete dan Tongkol Jagung Sebagai Bahan Bakar Alternatif. Skripsi Universitas Hasanuddin.

20. Sudrajat, R., 1983. Pengaruh Bahan Baku, Jenis Perekat, dan Tekanan Kempa Terhadap Kualitas Arang Briket. Laporan LPHH No. 165. Bogor.

21. Sunyata A. 2004. Pengaruh Kerapatan dan Suhu Pirolisa terhadap Kualitas Briket Arang Serbuk Kayu Sengon. Fakultas Kehutanan Institut Pertanian (INTAN) Yogyakarta.

22. Susanti, Eni. 2010. Pemanfaatan Kulit Jengkol Sebagai Bioherbisida Gulma Dan Biolarvasida Aedes Aegepty. Skripsi UNIMED. 
Rozanna Dewi, dkk / Jurnal Teknologi Kimia Unimal 5:1 (2016) 105-123

23. Sulistyanto, A. 2006. Karakteristik Pembakaran Biobriket Campuran Batubara dan Sabut Kelapa. Media Mesin. 7(2): 77-84.

24. Swisscontact. 1996. Analisa Kinerja Mesin Bensin Berdasarkan Hasil Uji Emisi.

25. Usman, M. Natsir. 2007. Mutu Briket Arang Kulit Buah Kakao dengan Menggunakan Kanji Sebagai Perekat. Jurnal Perennial, 3(2): 55-58.

26. Http://id.wikipedia.org/wiki/jengkol.jpg. diakses pada 22 September 2014.

27. Http://Indrayati.blogspot.com/2010/04/tanaman_Jengkol.html. diakses pada 10 Desember 2014. 